\title{
DEMOCRATISING OR DEMONISING THE WORLD HERITAGE CONVENTION?
}

\author{
Natasha Affolder*
}

\begin{abstract}
In recent disputes surrounding mining projects in and around World Heritage sites, the legitimacy of the World Heritage Convention regime has been attacked for a host of democratic failings. These accusations of 'democratic deficits' originate from both opponents and supporters of the Convention regime. They challenge the compatibility of international processes with national law and institutions, raise questions of accountability and transparency, and revisit tensions between state sovereignty and common heritage. This paper traces these perceptions of democratic shortcomings in the regime to certain misunderstandings of the Convention, to failed participatory processes at the national level, and to the challenges posed by vague and ill-defined treaty obligations. At the same time as it unveils democratic concerns about the evolving nature of the treaty regime, this paper challenges us to consider the democratic strengths of the Convention.
\end{abstract}

\section{INTRODUCTION}

In recent clashes surrounding mining projects on the borders of World Heritage sites in Canada, Australia and the United States, the World Heritage Convention (the Convention) has been transformed from a fairly innocuous and unknown international treaty to an instrument of "foreign domination,"1 a new model of "UN Takeover."2 Controversies over site listing and danger-listing processes, and the unclear consequences of site nomination for surrounding natural resource industry projects, have resulted in particularly venomous attacks on an international regime created to preserve natural and cultural areas of "outstanding universal value." 3 "World Heritage", reported

* LLB (Alberta), BCL (Oxford), DPhil (Oxford), Assistant Professor, University of British Columbia Faculty of Law. The author is grateful to the Symposium participants for their insightful comments and to Agnes Von Dem Hagen, Laura Track and Stephanie Case for their research assistance. An expanded version of this article is forthcoming in the Pace Environmental Law Review.

1 Amy Ridenour "Keep the Statute of Liberty Free: An Argument for Congressional Oversight of UN Land Designations in the US" (2002) National Policy Analysis 419.

2 Kim A O'Connell "Groups Foster Alarm About UN Park Takeover" (1996) 70(7/8) National Parks 26.

3 Convention Concerning the Protection of the World Cultural and Natural Heritage (16 November 1972) 1037 UNTS 151; (1972) 11 ILM 1358; TIAS No 8226, Preamble [the Convention]. 
a biologist after visiting the contested Daintree Rainforest World Heritage site, would be "uttered with a disgusted, bitter expression, as though the person had just tasted something awful and needed to spit." 4

This paper seeks to identify, disaggregate and scrutinise popular and academic critiques of the "anti-democratic" nature of the World Heritage Convention in the context of a trio of mining disputes in and around World Heritage sites. In the conflict surrounding the New World Mine near Yellowstone National Park, the Jabiluka Mine near Kakadu National Park, and the Cheviot Mine near Jasper National Park, mining interests have been pitted against World Heritage protection in the United States, Australia and Canada. In each of these democratic states, fears of "ceded sovereignty", an absence of democratic process, and a "takeover" of domestic land use decisionmaking are voiced. These challenges to the democratic credentials of the World Heritage regime are insufficiently disentangled from popular myths.

Interest in the "democratic deficits" in international law, highlighted by this Symposium, is emerging from scholars, judges, activists, and commentators of diverse perspectives. Although the Convention has attracted very little scholarly analysis, it is not immune from challenge from both popular and academic sources in this wave of heightened scrutiny of international processes and institutions. In 1999, Daniel Bodansky warned that the perception that "the international environmental process is insufficiently democratic" would grow to pose an increasingly significant challenge for international environmental law. ${ }^{5}$ It has. This examination of World Heritage disputes in three democratic states shows the extent to which problems of democracy can threaten to undermine a regime created to hold states accountable for the protection of heritage within their borders.

\section{BACKGROUND - THE WORLD HERITAGE CONVENTION AND A TALE OF THREE MINES}

\section{A The World Heritage Convention}

As an international environmental treaty, the Convention on the Protection of the World Cultural and Natural Heritage (World Heritage Convention) is fairly ancient. It was adopted by the General Conference of the United Nations Educational, Scientific and Cultural Organization (UNESCO) in 1972 and came into force in 1975. The Convention is marked by an unresolved tension between state sovereignty and the recognition that certain structures, sites and areas constitute the heritage not just of individual nations, but of humankind. ${ }^{6}$ The conflicting mandate of

4 William Laurance "Confrontation in the Outback: a Tropical Biologist's Tale" (2000) 47(2) Chronicle of Higher Education B12.

5 Daniel Bodansky "The Legitimacy of International Governance: A Coming Challenge for International Environmental Law" (1999) 93 Am J Int'l L 596, 596.

6 Convention, art 6(1). 
respecting national sovereignty and recognising communal obligations based on a collective interest is reflected in Paragraph 15 of the Operational Guidelines for the Implementation of the World Heritage Convention (Operational Guidelines): ${ }^{7}$

While fully respecting the sovereignty of the States on whose territory the cultural and natural heritage

is situated, States Parties to the Convention recognise the collective interest of the international community to cooperate in the protection of this heritage.

Much of the normative content of the current World Heritage regime is contained in these Operational Guidelines, which are created and frequently revised by a committee composed of 21 elected States Parties, known as the World Heritage Committee. As well as updating the Operational Guidelines, the Committee performs the gatekeeper functions of deciding which nominated sites will be included on the World Heritage List or the List of World Heritage in Danger (the Danger List), ${ }^{8}$ or should be removed from either list. As it is often through action initiated by the Committee that the World Heritage regime evolves, the rule-making role of the Committee requires elucidation. In this paper, the role of the Committee in creating and defining evolving obligations under the Convention is examined in the context of three controversial mining projects proposed alongside World Heritage sites.

\section{B A Tale of Three Mines}

\section{The Jabiluka Mine, Kakadu National Park, Australia}

Kakadu National Park is listed on the World Heritage List for both its natural and cultural heritage properties. When the park was nominated for inclusion on the World Heritage List, the property containing the Jabiluka mine was specifically excluded from the nomination, as was property containing two pre-existing mines, resulting in three "holes" in the site. The mine site thus occupied property just outside the boundaries of the Park in what might technically be designated a buffer zone. Scientists and conservation groups notified the World Heritage Committee in 1997 and 1998 that proposals to mine the Jabiluka deposit posed a threat to the integrity of Kakadu. ${ }^{9}$

To investigate the threats the mine posed to the cultural and natural heritage of Kakadu, the Committee decided in June 1998 to send a mission of experts to Kakadu. Led by the chairperson of the World Heritage Committee, the team included representatives from the scientific advisory

7 United Nations Educational, Scientific and Cultural Organization (UNESCO) Operational Guidelines for the Implementation of the World Heritage Convention (UNESCO World Heritage Centre, Paris, 2005) [the Operational Guidelines].

8 The List of World Heritage in Danger contains those sites for which "major operations are necessary and for which assistance has been requested" (the Convention, above n 3, art 11(4)).

9 Bureau of the World Heritage Committee "Reports on the State of Conservation of Specific Properties Inscribed on the World Heritage List" (30 September 1997) WHC.97/CONF.207/2, 3. 
agencies the International Union for the Conservation of Nature and Natural Resources (IUCN) and the International Council on Council on Monuments and Sites (ICOMOS). After consultation with a wide range of stakeholders including different levels of government, aboriginal groups, and conservation organisations, the team expressed "grave concern" about the threat of the mining project to the World Heritage site. ${ }^{10}$

An extraordinary session of the World Heritage Committee was convened specifically to decide whether to add Kakadu National Park to the Danger List in 1999. All three advisory bodies to the Committee (IUCN, ICOMOS, and the International Centre for the Study of the Preservation and Restoration of Cultural Property (ICCROM)) favoured such a danger listing and supported the view of the mission that mining adjacent to the Park should not proceed. ${ }^{11}$ The Australian government opposed listing Kakadu on the Danger List and undertook extensive lobbying of the Committee to prevent such a listing. At its $24^{\text {th }}$ Session, the Committee decided not to inscribe the Park on the Danger List despite the earlier recommendations of the mission and its advisory bodies. With respect to the cultural values of the Park, the Committee urged the Australian government to consult with the Mirrar traditional owners (who had originally appealed for Committee intervention). In 2004, the Committee applauded the news that the mining company Energy Resources of Australia had given a commitment that no mining would take place at Jabiluka without the agreement of the Mirrar people. $^{12}$

\section{The New World Mine, Yellowstone National Park, USA}

Yellowstone National Park, the world's first national park, was added to the Danger List in 1995 as a result of number of threats to the park, including the New World Mine. ${ }^{13}$ Proposals for the development of this gold and copper mine three miles outside the Park boundary were brought to the attention of the Committee in 1994 by the delegate of the United States. By the following year's session, the Committee had received detailed documentation on the situation from fourteen North American conservation organisations. ${ }^{14}$ Unlike the situation at Kakadu, the request for a Mission to

10 Graeme Aplin "Kakadu National Park World Heritage site: Deconstructing the Debate, 1997-2003" (2004) 42(2) Australian Geographical Studies 152.

11 Catherine Redgwell "The International Law of Public Participation: Protected Areas, Endangered Species, and Biological Diversity" in Donald Zillman, Alastair Lucas and George Pring (eds) Human Rights in Natural Resource Development: Public Participation in the Sustainable Development of Mining and Energy Resources (Oxford University Press, Oxford, 2002) 199-200.

12 World Heritage Committee "Decisions adopted at the $28^{\text {th }}$ Session of the World Heritage Committee" (29 October 2004) WHC-04/28.COM/26.

13 See Daniel L Gebert "Sovereignty under the World Heritage Convention: A Questionable Basis for Limiting Federal Land Designation Pursuant to International Agreements" (1998) 7 S Cal Interdis LJ 427, 428.

14 Bureau of the World Heritage Committee "Report of the Rapporteur, $19^{\text {th }}$ session" (31 July 1995) WHC.95/CONF.201/12, 23. 
Yellowstone came from the National Park Service and the Assistant Secretary of Fish and Wildlife and was supported by the Observer from the United States. The mission was carried out in September 1995 and discussed at the Committee's December meeting. ${ }^{15}$

In its decision to place Yellowstone National Park on the Danger List, the Committee noted that "... whether the State Party should grant a permit to the mining company or not is entirely a domestic decision of the State Party."16 The threat the mine posed to the park was eventually eliminated when the Clinton administration negotiated a land swap, allowing the federal government to acquire Crown Butte's interests in the mine. ${ }^{17}$ While Yellowstone National Park was removed from the Danger List in $2003,{ }^{18}$ the legacy of this claimed intrusion into domestic land use decisionmaking remains.

\section{The Cheviot Mine, Jasper National Park, Canada}

Like the New World and Jabiluka projects, the Cheviot Mine was proposed not within the National Park boundary, but a few kilometres outside the Park. Challenge to the Alberta government's approval of the mine came from local and national conservation groups, warning that permitting a mine on the border of Jasper National Park would amount to a breach of Canada's obligations under the Convention. ${ }^{19}$ Parks Canada representatives had similarly testified before the Cheviot Mine environmental review panel that the mine could jeopardise Canada's ability to meet its international obligations under the Convention. ${ }^{20}$ The potential threat to the National Park posed by the mine was brought to the attention of the Committee by the IUCN in 1997.

In March 1998, the director of the Committee requested that Canada's ambassador to UNESCO arrange for Canada to consult with Alberta about reconsidering its Cheviot Mine approval. ${ }^{21}$ Political responses to this international pressure varied from reassurance on the federal level that Ottawa was taking the UNESCO request seriously ${ }^{22}$ to outrage on the provincial level, expressed by

15 Ibid, 18

16 Ibid, 19.

17 Gebert, above n $13,428$.

18 World Heritage Committee "Decisions adopted by the $27^{\text {th }}$ Session of the World Heritage Committee" (10 December 2003) WHC-03/27.COM/24.

19 See Dennis Hyruciuk "Mine foes vow to fight back; Environmentalists eye international focus to protest Cheviot" (19 June 1997) Edmonton Journal Edmonton B5.

20 See Sierra Club of Canada "Making Mountain Park Reality" www.cpaws-edmonton.org/cheviot/ (accessed 1 January 2007).

21 Bureau of the World Heritage Committee "Report of the Rapporteur, 21st extraordinary session" (29 November 1997) WHC-97/CONF.207/5, p 5.

22 Andy Mitchell, cited in Ed Strusik "Feds to co-operate with UN request for data on project" (20 March 1998) Edmonton Journal Edmonton A6. 
the Albertan Environment Minister Ty Lund in the media: "It really bothers me when people from some other part of the world start telling the people of Alberta how to operate in the province of Alberta."23 Danger listing of Jasper National Park as a result of an approval of the Cheviot Mine did not occur but the issue continues to be monitored by the Committee. ${ }^{24}$

\section{WHAT IS THE DEMOCRACY PROBLEM IN THE WORLD HERITAGE CONVENTION? ${ }^{25}$}

In the disputes surrounding the Cheviot Mine, the New World Mine and the Jabiluka Mine, a host of democratic flaws of the Convention regime have been articulated. Many of these popular criticisms reflect the "paranoid lather"26 into which talk show hosts whipped their listeners during heated debates, and are based on misunderstandings of the operation of the Convention: ${ }^{27}$

What do the Statue of Liberty, Independence Hall, Jefferson's Monticello and Yellowstone National

Park all have in common? Each of these national treasures is now regulated according to the dictates of foreign bureaucrats rather than according to the will of the American people...

[UNESCO is an] organisation of the United Nations that is anti-American, anti-Constitution and bent on one world government... [it] claims control [over more than a dozen US World Heritage sites].

While it may be tempting to dismiss such criticisms outright as inaccurate and overstated, they are revealing of more profound concerns about democracy. Simply put, they raise questions about the representative and accountable nature of decision-making at the international level, and query whether the international level is an appropriate one to decide issues concerning land use. While climate change, ozone depletion, and the law of the sea may be accepted as environmental concerns appropriate for international regulation, decision-making surrounding land use, heritage protection and natural resource extraction are more fiercely guarded as issues of local governance.

23 See Les Sillars "This land is their land: UNESCO asks Ottawa to revoke approval of Alberta's Cheviot Mine" (6 April 1998) 9:31 British Columbia Report 22.

24 In its 2006 session, the Committee requested Canada ensure that "adverse impacts of the operation of the Cheviot Mine on the integrity of the property are minimised and mitigated." World Heritage Committee "Decisions of the $30^{\text {th }}$ Session of the World Heritage Committee" (23 August 2006) WHC-06/30.COM/19.

25 With apologies to Kal Raustiala, who asks "What is the Democracy Problem in International Law?" in "Sovereignty and Multilateralism" (2000) 1 Chi J Int'l L 401, 409.

26 Jonathan B Tourtellot "US Wary of World Heritage Status, Travel Editor Says" (10 October 2003) National Geographic Traveler.

27 Elisabeth McGeehan "US Sovereignty Violated by Allowing UN to Control US Historic Sites" (30 June 1999) Knight Ridder/Tribune; Richard J Rees "Stay out of UNESCO" (18 December 1993) Mansfield News Journal 4a. 
Democracy problems are both real and imagined. The imagined problems are no less significant than the real ones as they represent threats to the popular legitimacy of the Convention which may be as significant as any threats to its normative legitimacy. ${ }^{28}$

\section{A Misunderstanding World Heritage Processes}

The most frequent misunderstandings of the Convention voiced in the context of disputes over mining projects concern who nominates a site for inclusion on the World Heritage List and the legal consequences of World Heritage listing. World Heritage site nominations are portrayed in the media and in political debates as entirely UN-initiated exercises. The critical role of the state in site nominations is ignored. ${ }^{29}$ Despite frequent attempts to clarify this misunderstanding, it is frequently repeated. $^{30}$ The legal consequences of World Heritage listing are similarly misunderstood with rumours circulating that "listing results in the state's loss of legal title to the area inscribed on the List." 31

These misunderstandings are not unique to any one country and permeate conflicts in Australia, Canada and the United States. An Australian study identified conflict associated with World Heritage sites in Australia as emanating "from the confusion within the Australian polity about the nature of the Convention, how properties are listed and the nature of the management regimes entailed." 32 The authors of a study in the United States similarly concluded that "the majority of the population in the USA is ignorant and confused by the Convention." 33 Comparable observations are made with respect to Canada. ${ }^{34}$

28 See Bodansky's exploration of the concepts of popular legitimacy and normative legitimacy, above n 5, 601 .

29 Article 3 of the Convention states that it is for each State Party to identify the potential World Heritage site within its territory and article 11(3) requires state consent for inclusion of a property in the World Heritage List.

30 An International Centre for Settlement of Investment Disputes (ICSID) tribunal in the Southern Pacific Properties $v$ Egypt case attempted to clarify this misunderstanding, noting that the "choice of sites to be protected is not imposed externally, but results instead from the State's own voluntary nomination." Southern Pacific Properties (Middle East) Ltd v Arab Republic of Egypt (1992) 3 ICSID Rep 189, 225.

31 Trudie-Ann and Trevor C Atherton "The Power and the Glory: National Sovereignty and the World Heritage Convention" (1995) 69 Australian LJ 631, 648.

32 Tony Corbett and Marcus B Lane "World Heritage in Australia: An Uncertain Future" (1996) 32(3) Australian Parks and Recreation 39.

33 Kevin Williams "The Meanings and Effectiveness of World Heritage Designation in the USA" (2004) 7 Current Issues in Tourism 412, 414.

34 JG Nelson and EA Alder (eds) Toward Greater Understanding and Use of the World Heritage Convention Proceedings from a Canadian Seminar on the World Heritage Convention (Heritage Resources Centre, Waterloo (Ontario) 1993). 
Such misunderstandings are well illustrated by the frenzy which surrounded the New World mine project. The role of the United States government was ignored by critics characterising the inscription of Yellowstone on the Danger List as the result of unwelcome collaborations of environmental advocacy groups and the UN: "It is astonishing that a group of extreme environmentalists can invite in a few folks from the UN to circumvent laws that Americans and Montanans have worked hard for and lent their voices to." ${ }^{135}$

It is not possible, however, to attribute all the rancour expressed to confusion and misunderstandings. For some, the very concept of world heritage or common heritage is objectionable. Equally unacceptable is the view that the international level is an appropriate level for any sort of governance affecting local land use issues. Indeed, many of the attacks on the democratic credentials of the Convention appear to be modified versions of attacks once framed as objections based on sovereignty.

\section{B Failed Participatory Processes at the National Level Undermine International Processes}

The legal regime governing mining and world heritage is ill-defined and relatively unknown. Surprise is often voiced by both proponents and opponents of mining projects that World Heritage designation may (or may not) have domestic consequences for mining projects proposed adjacent to these sites. The lack of clarity governing the status of mining in and around protected areas creates uncertainty and dissatisfaction for a wide range of stakeholders. If mining activities are found to be incompatible with World Heritage status, then the processes by which these sites were initially proposed come under scrutiny, and are often found to be lacking in terms of their democratic credentials.

Part of the mismatch between the process of site nomination and contemporary expectations of community residents, conservation groups and mining companies is a result of an evolution of participatory norms in natural resource decision-making. The Convention predates many of the advances in participatory processes articulated in more recent instruments such as the Aarhus Convention. ${ }^{36}$ Criticisms voiced in Australia, Canada and the United States surrounding the Convention can often be traced to frustration with closed and non-participatory processes for site nomination at the national level, rather than any procedural defects at the international level. The failure of national governments to adequately consult stakeholders including sub-federal units in federal states, community interests, mining interests and affected indigenous peoples in nominating

35 Montana Senator Conrad Burns, quoted in Todd Wilkinson "Global Warning" (1996) 70(3/4) National Parks.

36 The World Heritage Convention predates the Aarhus Convention by over 25 years. See Convention on Access to Information, Public Participation and Decision-Making and access to Justice in Environmental Matters (Aarhus Convention) (June 25 1998) ECE/CEP/43. 
sites significantly undermines the Convention. These democratic shortcomings can be identified in Australia, the United States and Canada.

\section{Australia}

The Convention has received more popular, judicial and political attention in Australia than in any other country. Legally, the Convention has been the subject of significant litigation before the High Court and Federal Court, and has occupied a central role in the development of Australian constitutional law. The Convention has mobilised public opinion both for and against particular site nominations and projects, and has even ignited debate in several federal election campaigns. ${ }^{37}$

The nomination of the Daintree rainforest in Queensland in 1987 and the Tasmanian Dam and Tasmanian Wilderness have been among the most contentious site nominations in Australia and reveal the extent to which conflicts arise in the absence of collaboration between different levels of government and stakeholders. The nomination of the Daintree rainforest by the Commonwealth government unleashed a "Heritage War" between the Queensland and Commonwealth governments fought out in the Australian courts. ${ }^{38}$

An analysis of the public comments made to an inquiry initiated in 1995 by the House of Representatives Standing Committee on Environment, Recreation and the Arts (HORSCERA) on the Management of Australian World Heritage Areas reveals the common perception that the nomination process proceeds without consulting affected parties: ${ }^{39}$

With regard to consultation, an almost unanimous concern of resident communities and State and local government authorities was the absence of consultation during the nomination process. One local resident said of the Willandra Lakes nomination: "we learnt of the Willandra nomination via the newspapers, no notification, no consultation ... just bang, you're nominated."

Flawed consultation processes intensify suspicion toward the concept of World Heritage as an effective conservation or land management tool. ${ }^{40}$ They lead to the loss of opportunities to dispel rumours and misunderstandings surrounding the processes and implications of site designations.

Recent Australian legislation, the Environment Protection and Biodiversity Conservation Act 1999, requires the Australian Government, prior to submitting a nominated property to the Committee for inclusion on the World Heritage List, to use "its best endeavours to reach agreement"

37 See Ben Boer and Graeme Wiffen Heritage Law in Australia (Oxford University Press, Oxford, 2006) ch 3.

38 See, for example, Queensland v Commonwealth (1988) 62 AJLR 143 (HCA) Mason CJ. For a discussion of this litigation, see Donald R Rothwell and Ben Boer "The Influence of International Environmental Law on Australian Courts" (1998) 7(1) Rev EC Int Env Law 31.

39 Corbett and Lane, above n 32, 41.

40 Ibid. 
with any person who owns or occupies such property and with the government of the state or territory where the property is located. ${ }^{41}$ The section expressly provides that a failure to comply with these requirements "does not affect the submission of a property to the World Heritage Committee for inclusion in the World Heritage List or the status of a property as a declared World Heritage property." 42 The Act further requires public notice to be given when nominations are submitted to the Committee, the boundaries of the property are changed, or the property is added or removed from the World Heritage List. ${ }^{43}$

\section{United States}

The United States was an early instigator of the World Heritage concept in the 1970s, but is now the source of some of the most vocal attacks on the Convention. A powerful source of criticism of the Convention stems from the lack of congressional role in the processes for site nomination and maintenance decisions. ${ }^{44}$ Members of the United States Congress introduced the American Land Sovereignty Protection Bill as a legislative response to this democratic accountability gap. ${ }^{45}$ The legislation is intended to give Congress a central role in the designation process, allowing Congress to control the designation of sites. The Bill has been introduced into both the House of Representatives and the Senate a number of times, but has yet to be enacted into law. Analysis of the submissions made in debates surrounding the Bill reveals the fears and misunderstandings informing the debate: ${ }^{46}$

[Congressman Young:] "If the UN is allowed to gain control of the world's natural resources, it can control the nation's economy and therefore its people."

[Hon. Tim Hutchinson:] "Arkansans feel just as strongly about the issue of American sovereignty. They're offended when American troops are placed under foreign command. They're outraged when American soldiers are forced to wear United Nations uniforms or face a dishonourable discharge. And they're incensed when American land is designated an international reserve and subjected to international restrictions."

41 Environment Protection and Biodiversity Conservation Act 1999, Part 15, Division 1, ss 314(1) and (2).

42 Ibid, s 314(3).

43 Ibid, s 315

44 Matthew Machado "Mounting Opposition to Biosphere Reserves and World Heritage sites in the United States Sparked by Claims of Interference with National Sovereignty" (1997) Colo J Int'l Envtl L YB 120.

45 A Bill To Preserve the Sovereignty of the United States over Public Lands and Acquired Lands Owned by the United States, and to Preserve State Sovereignty and Private Property Rights in Non-Federal Lands Surrounding those Public Lands and Acquired Lands (104 ${ }^{\text {th }}$ Congress, $2^{\text {nd }}$ Session, 1996) HR 3752.

46 Charles Fernandes and Jeff Selle "Hands off the Land" (August 10 1996) Coeur d'Alene Press Coeur D'Alene (Idaho), reproduced in Public Hearing Before the Committee on Resources of the House of Representatives (September 12, 1996) HR 3752, 7-8; 3; 6 [Public Hearing]. 
This Bill addresses the "UN's insatiable appetite to interfere with US land management policy."

United States participation in the Convention is provided for in the National Historic Preservation Act Amendments $1980^{47}$ and through regulations. ${ }^{48}$ This legislation requires notification of the relevant committees of the House and Senate of all pending proposals when the Department of the Interior decides to nominate a property. It also requires written consent of every property owner before that owner's property can be nominated. ${ }^{49}$

Apart from criticisms arising from ideological opposition to the Convention, challenges are also the product of misunderstandings that arise from the fact that the most recent United States Tentative List (called the Indicative Inventory of 1982) is extremely dated and has not been updated to reflect developments in the Operational Guidelines. ${ }^{50}$ The United States Park Service acknowledges that consultation of property owners and other stakeholders in creating the 1982 List fell below standards "that would be deemed appropriate today."51 A new United States Tentative List is being prepared.

3 Canada

The World Heritage Convention has a low profile in Canada although nominations have on occasion attracted strong criticism, particularly for their failure to consult affected interests. The nomination of the Tatshenshini-Alsek region in northern British Columbia attracted criticism because of the lack of consultation of both First Nations and mining interests. In the Federal Parliament, a request was made to withdraw the nomination in 1994 as "undemocratic and unsupported"... carried out "with absolutely no public discussion, input or support." 52 Local First Nations reported that they had not been told about the World Heritage designation plan before it was announced. ${ }^{53}$ Facing significant opposition to the nomination based on the lack of First Nations consultation, Prime Minister Campbell reversed the nomination decision and instructed Canada's representative on the Committee to request a deferment of the application.

47 National Historic Preservation Act Amendments 198016 USCS § 471a-1, 1-2 [the Act].

48 World Heritage Regulations 36 CFR $\$ 73.7$

49 The Act, above n 47, § 470a-1(c).

50 Kevin Williams "The Meanings and Effectiveness of World Heritage Designation in the USA" (2004) 7 Current Issues in Tourism 412, 414.

51 National Parks Service "World Heritage Tentative List Project" www.nps.gov/oia/topics/worldheritage/ (accessed 1 January 2007).

52 Mr Mike Scott (13 December 1994) Canadian House of Commons Debates 8995.

53 See Jamie Lamb "NDP Tat move would've taken bite out of land that feeds us" (29 October 1993) The Vancouver Sun Vancouver A3. 
Tatshenshini-Alsek is not the only Canadian nomination where a failure to consult aboriginal peoples has been asserted. The Council of Yukon Indians expressed concern that it was not made aware of the nomination and designation of Kluane National Park Reserve, and that such designation might negatively impact their land claims within the Reserve's boundaries. ${ }^{54}$ Local First Nations similarly expressed concern about the nomination of Wood Buffalo National Park, and the implications of the nomination for their traditional hunting and fishing in the area. ${ }^{55}$

In compiling an updated list of nominated sites, the 2004 Tentative List, Parks Canada suggests "stakeholder support was a key consideration." ${ }^{56}$ The Tentative List revisions involved discussions with representatives of all provincial and territorial governments, selected aboriginal organisations, national stakeholder groups, municipal governments and other stakeholders near whose communities the sites were located. ${ }^{57}$ Admitting the lack of consultation in the past, Parks Canada acknowledges: ${ }^{58}$

Before 1990, the inscription process was viewed as the work of experts and it was considered sufficient to have the support of the relevant provincial government. Since 1990, nominations have engaged the public to a much greater extent. In some cases, the nomination process has been initiated by provincial or local authorities... In all cases, support for the nomination from local communities and appropriate Aboriginal groups is required before a nomination is put forward.

The government agencies responsible for World Heritage site nominations in Canada, the United States, and Australia have all made recent commitments to involving stakeholders in nomination decisions and consulting with local communities and affected peoples. This commitment was made in Parks Service communications in Canada and the United States. In Australia, it is contained in legislation, although the legislation specifies that a failure to follow this requirement does not invalidate the nomination. These developments follow revisions in 1999 to the Operational Guidelines which affirm that participation of local people, various levels of government and NGOs in the nomination process is essential. ${ }^{59}$

54 Nancy Elliot Origins, Impact and Future of World Heritage in Canada (MA Thesis, Trent University, 1995) 88 .

55 Ibid, 93-94.

56 Parks Canada "Updating Canada's Tentative List" www.pc.gc.ca/progs/ (accessed 1 February 2007).

57 Government of Canada "Periodic Report on the Application of the World Heritage Convention" www.pc.gc.ca/docs/ (accessed 1 February 2007) I.2.b.

58 Ibid, I.2.c.

59 Operational Guidelines, above n 7, para 123. 


\section{Concerns about the Evolving Nature of the Treaty Regime}

Concern about democratic accountability at the international level can be traced to the power of the autonomous World Heritage Committee and the fact that much of the normative content of the World Heritage regime is articulated in the Operational Guidelines, which the Committee produces, rather than in the Convention itself. Professor Francesco Francioni, a former chairman of the World Heritage Committee, explains this development: ${ }^{60}$

The principle of evolutive interpretation, which means identifying the meaning of a treaty provision not in light of the original intent and circumstances existing at the time of its adoption, but in light of the legal and social context at present, has found a remarkable application in the evolving body of the Operational Guidelines, periodically reviewed by the Committee and by innovative forms of treaty implementation, a notable example of which is the introduction in 1995 of the notion of systematic monitoring through periodic reported based on an expansive reading of Article 29 [of the Convention].

International environmental treaties are not expected to be static. But the development of norms requires some consensual basis to be regarded as legitimate. This is usually achieved by the parties themselves "breathing new life" into agreements. ${ }^{61}$ In other words, such "autonomous institutional arrangements" usually involve some informal meetings of States Parties to modify the Convention regime. $^{62}$

In contrast, the Committee produces new rules and obligations for States Parties through decisions requiring the agreement of a two-thirds majority of its membership, and through the evolving Operational Guidelines. ${ }^{63}$ While States Parties may strenuously object to Committee decisions, they do not withdraw from the Convention.

By ratifying the Convention, States Parties give general consent to a rule-making regime that empowers the Committee to update the Operational Guidelines. This general consent is distinct from any specific consent over individual decisions. The evolution of norms beyond the obligations consented to in the 1972 Convention is visible in a range of areas which impact on mining and world heritage protection including the power of the Committee to add properties to the Danger List without specific state consent, the provision for buffer zones around sites, and the articulation of rules governing mining in and around sites. Each of these examples reflects to some degree the

60 Francesco Francioni "The International Framework of Legal Instruments" (in "The Legal Tools for World Heritage Conservation" Workshop, Siena, 11-12 November 2002).

61 Edith Brown Weiss, "The Rise or the Fall of International Law?" (2000) 69 Fordham L Rev 345, 352.

62 See Robin R Churchill and Geir Ulfstein "Autonomous Institutional Arrangements in Multilateral Environmental Agreements: A Little-Noticed Phenomenon in International Law" (2000) 94 Am J Int'l L 623

63 The Convention, above n 3, art 13(8). 
challenges posed by vague or poorly-defined obligations in the original treaty. This absence of precise and rigorous obligations is not unique to the Convention, but is a flaw of modern treaties likely due to the lowest common denominator approach necessary to secure universal acceptance. More precise and affirmative obligations in the treaty itself could avoid some of the need for evolving obligations, and the accompanying concerns of democratic process such departures from interstate consensus bring.

\section{State Party consent for the inscription of a property on the Danger List}

The purpose of the Danger List is to alert the international community to threats to World Heritage sites. Inscription on the Danger List, according to the Convention website, "should not be considered as a sanction, but as a system established to respond to specific conservation needs in an efficient manner."64 Despite this characterisation, the Danger List is regarded as a form of "name and shame" 65 and some countries have loudly objected to potential danger-listing of their sites. Even the act of having Kakadu considered for the Danger List was characterised as a "slap on the wrist for Australia." 66

As a result of poor (or deliberately unclear) drafting, ambiguity has surrounded the question of whether a state must consent to having a property within its territory added to the Danger List. The drafting history of the Convention reveals that danger-listing should generally follow the request of a Member State and "must not lead to any kind of interference in the domestic affairs of the state or to any form of internationalism." ${ }^{167}$ The Operational Guidelines set out the criteria for inscribing a site on the Danger List and that information regarding a potential threat to a site must be verified with the State Party concerned, inviting its comments. ${ }^{68}$ However, the Guidelines contain the qualifying phrase "as far as possible", leaving room for the Committee to act in more of a unilateral fashion.

The Kakadu controversy coupled with threats to other World Heritage sites including the Kathmandu Valley in Nepal has forced the Committee to clarify whether state consent is required before a site can be added to the Danger List. In an Extraordinary Session meeting in 2003, the

64 UNESCO World Heritage Centre "World Heritage in Danger" www.whc.unesco.org (accessed 2 February 2007).

65 Redgwell, above n 11, 195.

66 See Aplin, above n 10, 163.

67 UNESCO "Final Report - Meeting of Experts to establish an International System for the Protection of Monuments, Groups of Buildings and Sites of Universal Interest" (10 November 1969) SHC/MD/4, para 72.

68 Operational Guidelines, above n 7, paras 174-184. 
Committee voted to reject Australia's proposed amendment to the Operational Guidelines that would give member states "veto power" for inscribing a site within its territory on the Danger List. ${ }^{69}$

This clarification may be perceived as an evolution in the powers of the World Heritage Committee, and is not one with which all States Parties agree. ${ }^{70}$ While the IUCN provides a cogent legal analysis articulating why the Committee has the power to place properties on the Danger List without State Party consent, ${ }^{71}$ the drafting history of the Convention reveals ambiguity on this point, and provides evidence that this may not have been the intention of the Convention drafters. ${ }^{72}$ The IUCN legal analysis distinguishes between "ordinary circumstances" where the inscription of a property on the Danger List presupposes a "request for assistance" and cases of "urgent need" where the Committee is empowered under Article $11 \S 4$ of the Convention to inscribe a property on the Danger list, absent a request for assistance, request for inscription, or the consent of the State Party. ${ }^{73}$ Thus in a departure from the traditional practice of not placing a site on the Danger List unless the State Party had first made such a request, the Committee added the old city of Dubrovnik to the Danger List without waiting first for a request for assistance.

\section{Buffer zones}

Buffer zones provide a further example of an obligation that is not in the Convention but was introduced through the Operational Guidelines. ${ }^{74}$ The concept of a buffer zone reflects the principle that "World Heritage sites should be surrounded by concentric regions of graduated

69 World Heritage Committee "Decisions adopted by the World Heritage Committee at its 6th extraordinary session" (27 May 2003) WHC-03/6 EXT.COM/8.

70 The United States, for example, has expressed the opinion that state consent is required before a site can be added to the List of World Heritage in Danger.

71 See International Union for the Conservation of Nature and Natural Resources (IUCN) "Draft Operational Guidelines: An Analysis of the Legal Issues: Responding to the $2^{\text {nd }}$ Draft Operational Guidelines and issues raised during the Drafting Group of October 2001" (presented to the World Heritage Committee, 14 May 2002).

72 See UNESCO "Draft Report: Special committee of government experts to prepare a draft convention and a draft recommendation to Member States concerning the protection of monuments, groups of buildings and sites" (4-22 April 2002) SHC.72/CONF.37/19, paras 26-30. ("These two lists are to be regularly kept up to date and distributed, and international assistance is to be used for property appearing in either one of these lists or in both of them. The inclusion of a property in these lists requires the consent of the State Party concerned. Although a request by the latter will be necessary before a property may be included a property in the "List of World Heritage in Danger", the Committee will be able to include a property in the "World Heritage List" without the State concerned having requested it, but on condition that it consents.") (emphasis added).

73 World Heritage Committee "Legal Considerations Concerning the Inscription of Properties on the List of World Heritage in Danger and the Deletion of Properties from the World Heritage List" (3 December 2002) WHC-03/6 Ext.Com/INF.4A, para 24.

74 Operational Guidelines, above n 7, para 104. 
restrictiveness to provide a margin of safety around the sites themselves." ${ }^{175}$ The Operational Guidelines require the creation of adequate buffer zones "whenever necessary for the proper conservation of the property." ${ }^{176}$ If buffer zones are not included in a nomination, the onus is on the state to explain why they are not required. ${ }^{77}$

Buffer zones, as the Yellowstone controversy illustrates, are contentious and the subject of democratic concern, particularly given their potential to encroach on the property rights of private landowners. Prior to the danger listing of Yellowstone National Park in 1995, President Clinton issued an order that effectively created buffer zones around the National Park. ${ }^{78}$ This "led to allegations that the World Heritage Convention had played a significant role in land management decisions concerning federal lands, thereby impinging on United States sovereignty."79

The buffer zone requirements currently articulated in the Operational Guidelines are not enforced, or are unevenly enforced at best. Many sites added to the list do not include a buffer zone. The practice of failing to respect this provision of the Operational Guidelines, and of nominating sites without a buffer zone, may reflect the lack of state consensus underlying this requirement.

3 Mining and World Heritage: the locus of decision-making

There is no express prohibition on all mining within World Heritage sites in the text of the Convention, nor is it clear that such a sweeping prohibition could be implied from the Convention text. It may, however, be that certain mining activities either in, or near, World Heritage sites would lead to a breach of the Convention.

The World Heritage Committee has taken some steps to address the uncertainty and lack of clarity with respect to mining and World Heritage sites. Much of the work in this area has been done by the IUCN, which advises the Committee on issues affecting natural heritage. In 2000, the IUCN's World Conservation Congress adopted Recommendation 2.28 (the Amman Recommendation) which declared that mining should be "prohibited by law or other effective means" in four categories of protected areas. ${ }^{80}$ The "Position Statement on Mining and Associated Activities in Relation to Protected Areas" on which the Amman Recommendation was based, was

75 John Charles Kunich "Losing Nemo: The mass extinction now threatening the world's ocean hotspots" (2005) 30 Colum J Envtl L 1, 70.

76 Operational Guidelines, above n 7, para 103.

77 Ibid, para 106

78 Machado, above n 44, 124.

79 Ibid.

80 IUCN "Recommendation 2.82: Protection and conservation of biological diversity of protected areas from the negative impacts of mining and exploration" (in Proceedings of the World Conservation Congress, 4-11 October 2000). 
submitted as a working document to the Committee, which created some confusion: the Delegate of Canada articulated support for the Position Statement, while the United States required reassurance that the document "was "for information only" and it was "noted for the record that this document [was] not recommended for adoption by the Committee". 81

Following recommendations of the Committee, a Technical Workshop on World Heritage and Mining took place in Gland, Switzerland in 2000, with the IUCN, UNESCO and the International Council of Metals and Environment (ICME, representing the mining industry) as participants. The Workshop's report ${ }^{82}$ was discussed by the Committee ${ }^{83}$ and a Working Group on World Heritage and Mining created.

The absence of clear national or international rules clarifying the relationship between mining and World Heritage sites has led to initiatives emerging outside governmental, or intergovernmental, processes. One such process resulted in the August 2003 "No Go Pledge" by fifteen of the world's largest mining companies. The companies committed not to explore or mine in World Heritage properties and to ensure that "existing operations in World Heritage properties, as well as existing and future operations adjacent to World Heritage properties" would not be incompatible with the outstanding universal value for which these properties were listed. ${ }^{84}$

The No Go Pledge was the product of the International Council on Mining and Metal's effort, not a collaborative or multi-stakeholder initiative. It was, however, motivated by earlier dialogues with the IUCN surrounding the issue of mining and World Heritage sites, and by fear on the part of the mining industry that in the wake of the Amman Resolution and controversies over projects such as the Jabiluka mine, reputational risk might get out of hand.

This 2003 "No Go Pledge" was copied by Shell on August 27, 2003 with a commitment "not to explore for or develop oil and gas resources within natural World Heritage sites". ${ }^{85}$ Goldman Sachs

81 World Heritage Committee "Report, Twenty-third Session" (2 March 2000) WHC-99/CONF.209/22, X.56.

82 IUCN, UNESCO and International Council on Metals and the Environment Proceedings of the Technical Workshop on World Heritage and Mining Gland, Switzerland, 21-23 September 2000 (IUCN, UNESCO, ICME, Gland, 2001).

83 World Heritage Committee "Report of the Rapporteur of the twenty-fourth extraordinary session of the Bureau, Cairns, Australia, (23-24 November 2000)" (25 November 2000) WHC-2000/CONF.203/INF.7 and World Heritage Committee "Report of the twenty-fourth session" (16 February 2001) WHC2000/CONF.204/21

84 International Council on Mining and Metals "ICMM Position Statement on Mining and Protected Areas" (20 August 2003) Press Release.

85 Sir Phillip Watts, Chairman of the Committee of Managing Director, Royal Dutch/Shell Group "Working together for Biodiversity" (27 August 2003) Press Release. 
made a similar pledge on December 20, 2005 committing itself to "not knowingly [finance] extractive projects or commercial logging in World Heritage sites". 86

These private initiatives to define global rules surrounding natural resource extraction and World Heritage sites are increasingly common. They form part of a growing number of attempts to enunciate international standards or rules outside a framework of intergovernmental agreement. These processes are not intended to be open, inclusive, or democratic. Their emergence should highlight some of the democracy-enhancing qualities of existing intergovernmental environmental regimes.

\section{Participation and Transparency in Decision-making}

Scrutiny of international processes, whether the processes are industry-led or intergovernmental in nature, is frequently a response to concerns about transparency and openness. The World Heritage regime is no exception. Concerns are voiced about the composition of the Committee, access to information, and participation in decision-making on the part of interested organisations and individuals. On its face, the Convention does not appear open to non-state participants (other than its advisory bodies) nor transparent in terms of its decision-making. However, such a formalistic critique of the treaty is misleading.

While the Convention does not formally provide for the public dissemination of its decisions, information about the workings of the Committee including reports of the meetings of Parties and Committee deliberations are publicly available on UNESCO's comprehensive website. The Committee, and its advisory bodies, are also frequently provided with information from a range of NGOs, park managers and research organisations. These actors occupy the crucial role of "watchdog", alerting the Committee about threats to sites and the inadequacy of protection measures. While only state representatives may submit nominations for sites, requests for danger listings can come from any source and the Committee has relied on NGO submissions in a number of danger listing decisions. NGOs, in joint initiatives with academic institutions, are particularly active in compiling petitions requesting the addition of sites to the Danger List as a result of the threats posed by climate change.

Active involvement of NGOs in the Convention can be viewed either as a sign of the democratic health of the regime, ${ }^{87}$ or conversely as an indicator of its anti-democratic nature, revealing the

86 World Heritage Centre "Goldman Sachs Declares World Heritage Sites Off Limits" (20 December 2005) News Release.

87 See Raustiala, above n 25, 415. ("Broadening the scope of popular and interest-group participation in international law-making is, in my view, not anti-democratic but pro-democratic."). 
extent to which interest groups dominate global institutions. ${ }^{88}$ The Convention provides that NGO's "with similar objectives" to the IUCN, ICOMOS and ICCROM may "attend the meetings of the Committee in an advisory capacity." 89 No similar provision exists to allow other non-state actors such as mining companies or sub-federal actors such as provinces or states to participate in Committee decision-making. The Committee was thus unsure how it should react to a Queensland delegation which in 1988 arrived in Paris to formally object to the Queensland Rainforest site listing. Ultimately, at the suggestion of the Canadian delegate, the Queensland contingent was permitted to attend the meeting and the Queensland Environment Minister was allowed to speak. ${ }^{90}$ Mining companies have not been similarly welcomed into Committee meetings, but have been permitted to provide written submissions to the Committee.

\section{The Committee}

The Committee has not attracted charges of domination by a small group of nations or a lack of representation of developing countries. Since the Committee was created, Brazil, Egypt, Mexico, Lebanon, and Senegal have collectively served on the Committee a total of 87 years (15 mandates), compared to the 60 years (11 mandates) collectively served by the UN Security Council's 'Big Five' (China, France, the United Kingdom, the United States, and the Russian Federation). ${ }^{91}$ But calls for new procedures such as quotas to ensure better regional representation are still voiced, and to date have been resisted by the Committee. ${ }^{92}$

\section{Expert decision-making}

Expert decision-making and participatory processes traditionally rely on conflicting bases of legitimacy. ${ }^{93}$ Of these two bases of legitimacy, the World Heritage regime relies most strongly on appeals to expertise. The expertise of the Committee and its advisory bodies are invoked to buttress

88 See Jeremy Rabkin "International law vs. the American Constitution - Something's Got to Give" (Spring 1999) The National Interest Shrub Oak (NY) ("Actual governments can be awkward for UN agencies. It is usually much easier to deal with constituencies that do not themselves have to pay UN bills or submit to UN directives. NGOs - a sort of phantom citizenry - are the perfect partners for the phantom authority exercised by UN agencies.").

89 The Convention, above n 3, art 8(3).

90 Thomas H Edmonds "The Queensland Rainforest and Wetlands Conflict: Australia's External Affairs Power" (1990) 20 Envtl L 387, 411.

91 Compiled from UNESCO "14 $4^{\text {th }}$ General Assembly of States Parties to the Convention Concerning the Protection of the World Cultural and Natural Heritage (9 July 2003) WHC-03/14.GA/INF.9B.

92 The Committee has rejected as "rigid" and unsuitable suggestions that it should consider establishing new procedures for elections such as regional quotas. World Heritage Committee "Equitable Representation of Different Regions and Cultures in the World" (9 November 1990) CC-90/CONF.004/INF.4.

93 Bodansky, above n 5, 620. 
individual decisions and make them appear less political, more objective, and more palatable. This invites the claim that: ${ }^{94}$

scientific objectivity has facilitated regime maintenance [in the case of the Committee]...Despite a lack of formal enforcement powers, the World Heritage Committee has been able to rely on objective and neutral scientific evidence to avoid the politicisation of decision-making processes and to enhance compliance.

Such claims obfuscate the inescapable reality that many issues the Committee decides, such as the threats posed by mines situated in and around World Heritage sites, involve not only technical questions, but questions of values. An approach where primacy is given to science is not always followed. ${ }^{95}$ Scientific findings are contested, ${ }^{96}$ and the credibility of scientific "experts" attacked. ${ }^{97}$ Finally, invoking "expertise" can undermine democratic participation, at both the national and international levels: ${ }^{98}$

The involvement of "experts" in the decision-making process means as soon as an issue is institutionally construed as demanding expertise (such as the identification of world heritage values), the scope for legitimate participation is markedly diminished. Only those larger environmental groups with scientific and technical information and resources (such as the Australian Conservation Foundation), are in a position to challenge or question the credibility of government decisions.

The relationship between protected areas and natural resource extraction is deeply value-laden and is an issue on which domestic consensus is difficult to form. Many resource-rich countries have complicated and non-finalised legal regimes governing mining in and around protected areas. Whether mining should be allowed in and around World Heritage sites is not a question that science can answer on its own. Thus, expertise alone is unlikely to provide a sufficient basis for legitimating international rules on mining and World Heritage sites.

94 S Javed Maswood "Kakadu and the Politics of World Heritage Listing" (2000) 54(3) Australian Journal of International Affairs 357, 357.

95 Consider the decision of the Committee not to add Kakadu to the Danger List despite the recommendations of the Committee's "expert" advisory bodies.

96 The scientific findings relied on by the expert bodies questioned the science behind the Australian government's Environmental Impact Study (EIS). See Maswood, above n 94, 364.

97 Australian Federal Environment Minister Robert Hill attacked the credibility and independence of the IUCN and ICOMOS following their Mission to Kakadu. See Sophie Boukhari "The Kakadu Affair Shakes the Heritage World" (October 1999) The UNESCO Courier Paris www.unesco.org/courier/ (accessed 1 January 2007).

98 Benjamin J Richardson "A Study of Australian Practice Pursuant to the World Heritage Convention" (1990) 20 Environmental Policy and Law 143, 150. 


\section{CONCLUSION: ASSESSING THE DEMOCRATIC STRENGTHS OF THE CONVENTION}

Why is it that the democracy-enhancing qualities of international environmental treaties are so infrequently discussed? Are democratic deficits so much more pervasive, or more interesting? Accusations of democratic flaws have a particular potency that seems unmatched by articulations of the democratic strengths of international processes. Peter Sand reminds us that the "essence of environmental public trusteeship, as embodied in the [World Heritage] convention, is the democratic accountability of states for their management of trust resources in the interest of the beneficiaries - the world's 'peoples."'99 The Convention thus holds states responsible for the protection of World Heritage sites within its borders. It does so by providing a forum for considering the concerns of non-state and sub-state interests and by raising issues that states may prefer to suppress.

The 2003 "No Go Pledge" and other private sector initiatives that have followed it further suggest that the Convention embodies certain democratic strengths when compared with alternative regimes for global governance. Industry-led initiatives to define acceptable rules governing natural resource extraction and World Heritage sites do not attempt to be open, inclusive, representative, or participatory. Yet they are growing in number, largely unquestioned.

This analysis of perceived democratic weaknesses in the World Heritage regime traces these challenges to failures of national law and institutions in providing participatory mechanisms for site designation and maintenance decisions, to uncorrected misunderstandings of the World Heritage system, and to an evolving treaty regime in which national obligations with respect to mining projects situated in and around World Heritage sites remain largely unclear. The Convention faces serious challenges in the coming years. Increasing population and demand for natural resources and other development pressures will inevitably create conflict with a regime designed to conserve areas of outstanding natural and cultural heritage. Accusations of a lack of democratic accountability pose equally serious threats. Given the particular potency of accusations of democratic flaws, the challenge lies in constructively democratising the Convention, not just demonising it.

99 Peter H Sand "Global Environmental Change and the Nation State: Sovereignty Bounded?" in Gerd Winter (ed) Multilevel Governance of Global Environmental Change: Perspectives from Science, Sociology and the Law (Cambridge University Press, Cambridge, 2006) 519, 538. 
